\title{
Attitudes and Perceptions of Middle School Students Toward Competitive Activities in Physical Education
}

\author{
Eve Bernstein ${ }^{1}$, Sharon R. Phillips ${ }^{2}$, Stephen Silverman ${ }^{3}$ \\ ${ }^{1}$ Queens College, ${ }^{2}$ University of Waikato, ${ }^{3}$ Columbia University
}

The attitudes and perceptions of middle school students toward competitive activities in physical education were examined. Ten boys and 14 girls volunteered (11-high-skilled, 11 moderate-skilled, and 2 low skilled students) in 6th and 7th grade from a total of 6 schools, all offering competitive activities. Data collection was conducted over several months and included focus groups consisting of students of mixed skill levels, observations of competitive class activities, and informal interviews with teachers. The three major themes that emerged were, having fun in competitive activities, not all students were attaining motor skills necessary to participate in activities due to a lack of time to engage in appropriate practice, and the structure of competitive activities affects student experience

Keywords: skill level, focus groups, team structure

Competitive activities are pervasive in physical education programs in the United States. Students experience a variety of both sport and competitive activities that are offered during the school year. The use of competitive activities in physical education class might be used to promote physical activity and develop skill, build character, promote sportsmanship, and prepare students to live and work in a competitive environment (Brown \& Grineski, 1992; Drewe, 1998; Goldstein \& Iso-Ahola, 2006; Hager, 1995). The competitive activities presented may either enhance participation interest in the activity, or may exclude students from successful and enjoyable participation experiences and detract from interest in participating in the activity presented (Brown \& Grineski, 1992; Kohn, 1999; Solmon, 1996; Ntoumanis, 2001). This lack of participation might be due to a lack of skill (Ennis, 1996, 2003; Silverman, Kulinna \& Crull, 1995). While students experience competitive activities in physical education class, experiences may vary depending upon the success of participation and the way the activity and competitive environment is structured.

Bernstein is with Queens College, Department of Family, Nutrition, and Exercise Science, Flushing, NY. Phillips is with University of Waikato, Sport and Leisure Studies Department, Hamilton, New Zealand. Silverman is with Teachers College, Columbia University, Biobehavioral Sciences, New York, NY. 
Although curricular models may differ in structuring competition, inherently competition may be defined as achieving success or not having success, or winning and losing. For example, competitive activities can be zero sum, negative sum, or contingency activities. Zero sum activities are defined as one person as a winner and one person as a loser. Negative sum activities imply that there are many losers and few winners, and contingency activities are dependent on the success of a skill (Brown \& Grineski, 1992; Kohn, 1999). These activities conclude that continuation of play is dependent upon success, or the ultimate skill of the player or student. Therefore, in many competitive activities having skill can facilitate participating in the competitive activity presented. Not having skill can hinder participation.

Students with different skill levels have different experiences in physical education class (Manson, 2003; Silverman, 2005; Silverman \& Subramaniam, 1999; Solmon \& Lee, 1996). A student, who has lower skill often has difficulty performing a skill in class and does not receive adequate appropriate practice trials (Silverman, 1993). Several factors may contribute to student engagement and skill level in competitive activities. Factors such as time and appropriate practice (Meltzer, 1989; Silverman, 1985, 1990; Silverman, Tyson, \& Morford, 1988), skill progression, and task presentation (Rickard, 1992; Rink, 1994; Silverman et al., 1995) can help develop students' skill and increase students' success in an activity. If students experience success, and that success contributes to participation, students might want to continue with the activity. If competition is used appropriately it can be a tool for skill development while students are successfully experiencing competitive tasks (National Association for Sport and Physical Education [NASPE], 2009).

Success, or lack of success could also affect students' attitudes and perceptions toward the subject. As skill is an important part of participation in competitive activities, little is known about the attitudes and perceptions of students toward competitive activities in physical education class. Attitude theory, which serves as the theoretical framework for this study, suggests that affect and cognition or students' knowledge may affect how students participate in an activity (Ajzen, 2005). Attitudes may have an effect on students' perceptions about physical education, and these attitudes and perceptions may affect students' behavior (Pajares, 1992; Zimbardo \& Leippe, 1991). Beliefs can be strong or salient but can change over time (Ajzen, 2005). Beliefs can determine attitude, and attitude, positive or negative, can affect behavior. As competition is used to assist learning for authentic experiences, a student's belief of their ability may affect participation in those experiences (Ajzen, 2005; Carlson, 1995; Pajares, 1992; Silverman \& Subramaniam, 1999). If students do not have the skill to enter into game play, this might affect learning. If a student has a negative experience in competitive activities in physical education, he or she might not want to participate (Carlson, 1995; Ennis, 1996). Beliefs can change positively, if a student has a positive experience in these authentic activities (Ajzen, 2005; Silverman \& Subramaniam, 1999). In the case of this study attitudes and perceptions toward an activity can be powerful and can affect whether a student chooses to participate, and how and what they ultimately learn (Carlson, 1995; Silverman \& Subramaniam, 1999).

Students who have positive experiences in physical activities may want to continue those activities (Silverman, 2005; Solmon \& Lee, 1996; Subramaniam \& Silverman, 2002). Conversely, students who feel they are unsuccessful at an activity may not enjoy physical education (Carlson, 1995; Portman, 1995; Silverman, 2005; 
Subramaniam \& Silverman, 2002) and may not want to continue participation. If the goal of physical education is to promote a lifetime of physical activity, it is important for students to have an enjoyable experience. Therefore, it is relevant to examine the experiences students are having.

Students' physical activity begins to decline after adolescence (CDC, 2006; Sallis, Prochaska, \& Taylor, 2000) and it is important to listen to the voices of middle school students regarding their experiences with competitive activities in physical education class (Carlson, 1995; Dyson, 1995; Graham, 1995; Hopple \& Graham, 1995; Portman, 1995). Gaining insight into how students feel about the competitive activities in which they participate may provide valuable information to curriculum designers and educators to make informed decisions on creating effective programs. Students' voices and observations can reflect the experiences they are having and can provide invaluable information (Cothran, Kulinna \& Garrahy, 2003; Graham, 1995; Hopple \& Graham, 1995; Portman, 1995; Ravizza \& Stratton, 2007) toward understanding their experiences in the competitive activities offered in physical education class.

The purpose of this study was to examine the attitudes and perceptions of middle school students toward competitive activities in physical education class. Students shared their experiences in competitive activities in physical education class, and supported by observations, gave an analysis of those experiences. These experiences are important to explore, as they may affect students' attitude and perceptions of competitive activities. This in turn, may affect participation.

\section{Method}

\section{Pilot Testing}

The open-ended semistructured interview questions used in the focus groups were conceptualized and developed by reviewing literature in physical education, and theory related to attitude and focus group protocol (Carlson, 1995; Graham, 1995; Morgan, 1997; Portman, 1995; Patton, 2002; Schensul, 1999; Subramaniam, \& Silverman, 2002; Tjeerdsma, Rink, \& Graham, 1996). After the questions were developed they were extensively reviewed by both professionals in the field of physical education and piloted with middle school students. Revisions and modifications occurred until pilot focus groups indicated the questions resulted in data saturation. In addition, all other procedures (e.g., observations and informal interviews) were extensively piloted.

\section{Procedures}

Participants. Six urban schools, one public and five private, took part in the study. The physical education classes observed focused on competitive activities. Five schools used a multiactivity curricular model and one school used a modified sport education model. Classes would practice skill and then take part in full-fledged game play. When the modified sport education model was observed modified game play was used.

Twenty-four students (10 boys, 14 girls) from the six different schools participated in the study. The students ranged from ages 11-13. There were 11 high-skilled 
students, 11 moderate-skilled students, and 2 low-skilled students. Students were rated as high, moderate and low-skilled. Ratings were designated by teachers and confirmed by the researcher's observations during physical education class.

Focus Group. The questions that were refined as a result of the pilot study were used to guide the focus groups. Some questions that were asked are included below, and students were probed on their responses. The following six categories were discussed by the students, (a) background information (e.g., grade, age, and pseudonym the student would like to use for the study), (b) introduction (e.g., questions regarding general activities the students liked and did not like), (c) perception on activities presented in physical education (i.e., questions on what activities were offered in their physical education classes), (d) perception on skill level (e.g., How does your teacher help you do the activity better? Can you tell me a time when you improved in an activity after practice? How do you know when you have improved in activity?), (e) perception on competition (i.e., questions asked to define competition, winning and losing), and (f) perception on competition in physical education class (e.g., How are the teams picked? Are your friends on the team? How do you feel when your friends are on the team? How do you feel when your friends are not on the team? When playing does everyone cooperate? Do you come up with strategies when you're on the team? Do people listen to your strategies? Do you feel that you belong to a group when you are in physical education? What should competition be like in physical education class?).

Nonparticipant Observations and Field Notes. For each school, three class sessions were observed. Nonparticipant observations and recorded field notes (Bogdan \& Biklen, 2006; Patton, 2002) were taken during each observed class. The competitive activities observed were basketball, baseball, European handball, handball, floor hockey, running activities, tennis, and variations of games based on capture the flag and tag. These units lasted appropriately three to five weeks.

Informal Interviews. Informal interviews of teachers were held before and after each class session that was observed. Teachers were asked questions regarding the lesson and the class participation. Notes were taken on the teachers' responses. These informal interviews were used to gain an understanding of the teachers' actions, thoughts, and feelings that cannot be observed (Hopple \& Graham, 1995; Seidman, 2006).

Data Analysis. Field notes and observations, focus group interviews, and informal interviews with the teachers were immediately transcribed. All focus groups interviews were member checked for accuracy by the participants. Any changes were immediately made to the transcripts. All documents were then entered into N-VIVO 8 (QSR International, Victoria, Australia) and were analyzed over a process of three months for various themes using the constant comparative method (Glaser \& Strauss, 1967; Strauss, 1987).

The document then went through several rounds of independent peer review, by a coauthor, with extensive experience in physical education and qualitative analysis. Many revisions were made before the themes were finalized. To ensure trustworthiness and credibility observations, field notes, focus group and informal interviews were triangulated and constantly compared with all three data sources 
to support themes by the author and peer reviewer. In addition all data collected were checked for negative cases.

Researcher's Background. The first author, who collected data in the schools, was a physical education doctoral student when the study took place. She has extensive experience teaching in physical education and martial arts in primary and secondary schools as well as at the collegiate level as a teacher educator. To check for any biases that may have occurred in the study, and to ensure trustworthiness and credibility, one of the coauthors acted as a peer reviewer.

\section{Results}

Three major themes emerged during the process of data analysis. The first theme was having fun in competitive activities in physical education class. Under this theme, there were various subthemes that included: (a) high-skilled students and fun (b) moderate-skilled students and fun, and (c) low-skilled students and fun. The second theme was all students are not developing skill during competitive activities. This theme had several subthemes that included: (a) passing as a rite of passage, and (b) standing around. The third theme was the structure of competitive activities affects student experience. This theme had several subthemes: (a) structuring teams, (b) team leaders, (c) students who "hogged the ball," and (d) students who mocked when winning or became too serious when they lost.

\section{Having Fun in Competitive Activities in Physical Education Class}

Students enjoyed a variety of activities offered in physical education class. Each school offered several units of various competitive activities. This theme emerged as students discussed their perceptions of competition and competitive activities in physical education class.

The physical education programs and teachers in those programs stressed "fun" as an important part of the student's experience in each of the units and classes they offered. The students were excited discussing the different activities offered by the schools. Overall, students felt it was fun to work with friends during competitive activities in physical education class. Students, however, who were high, moderate, or low- skilled viewed "fun" and working with friends slightly differently. The idea of activities being "fun," might have mitigated skill learning, as students of various skill levels perceived fun differently. High-skilled students felt that activities presented in physical education class were not as competitive as regular sport and winning or losing against friends was fun. Moderate-skilled students felt that activities that were challenging were fun, and low-skilled students like to work with other students to make alliances and to cooperate.

High-Skilled Students and Fun: Not That Competitive. In many of the competitive activities offered in physical education class, high-skilled students made plays with relaxed confidence, and actively participated in competitive games. Some of the high-skilled students viewed the competitive activities offered in physical education class as fun and not that competitive. They believed physical 
education class was a place to learn and have fun with your friends, rather than to take part in a high-stakes competition. Thus, physical education class was seen as less competitive than team sports.

Anita, explained the activities she enjoyed in physical education class as "basically for fun." She also contrasted competitive sport in physical education class with competitive activities outside of class by stating, "if I lose [in physical education class] it doesn't feel bad, it's kinda for fun, but if it is like travel soccer or something and you... you can get kicked out of the tournament or something then that kinda feels bad."

Anita thought the ideal competition in physical education class "shouldn't be too roughly enforced...we should cut down on...score keeping, ...cause we're kids and we just need to have fun." Sally had the same sentiment as Anita, "I don't think scoring is...the most important thing is having fun and learning, and scoring is just a tiny fraction of that." Sally noted that in physical education class, "there is not much competition." Sally would also add, that in physical education class "we don't do things that aren't fun."

The pressure of competition also was not as great in physical education class, because the students felt that they were engaged with their friends rather than a team that they did not know. In one focus group there was a discussion between two students, as Juan stated, "competition is, like, fun, because you're doing it with your classmates and people you know." Even if you "beat your friends," as Kealy stated, it is "fun." This might be due to the fact that students do not feel the pressure of competition in physical education class. Kealy felt that competition with her friends was fun because, "even if you are a little better or a little worse... sometimes you can get a laugh out of it."

Moderate-Skilled Students and Fun: Challenging Activities. Moderate-skilled students also felt that competitive activities were fun. Whereas high-skilled students enjoyed their friends and the less competitive atmosphere of physical education class, moderate-skilled students enjoyed playing with their friends as well. They also enjoyed, however, the challenge of improving in an activity. In observations of several schools, moderate-skilled students were participating actively and concentrating on skill work in the activities presented. Throughout the focus groups, the ideas of excelling and being challenged were repeated.

In several schools with a competitive focus, moderate-skilled students spoke on this subject. Vitto, when discussing floor hockey stated, "it was something I excelled in, I, I look forward to it. It is more enjoyable in phys. ed. when it's something you are good at." He went on to add that, "competition, it helps you, like a way to do even more." Clark stated that the ideal competition in physical education class "should look like a bunch of friends having fun." He went on to add that having fun and difficulty were intermixed, "well, playing against other teams trying to win, you're like having fun but trying to win, like fun, but it's hard." Steve, spoke on being challenged, as he stated that, "the most fun I've had is, like, when basketball, was the most educating, and, ah, I tried my hardest. I felt like it really challenged me a lot." In observations of physical education class Steve was actively engaged, and would work hard at tasks that were difficult for him.

Dorothy felt that the idea of competition in physical education class was fun, because it prepared them for the challenge of competition in high-school sports and 
those competitive teams. As she stated, "physical education is a good thing, where we can get our competition on." In one focus group there were several interactions regarding challenging activities. Mia, enjoyed the challenge experienced in learning new activities in physical education class. She felt that it was "fun to play something you haven't played before," because she could "go through not being able to do anything, to being able to do it." Oscar had a slightly different experience. He felt challenge lay not in new activities, but rather the challenge lay in whom he played against. He felt "to play with equals...to be competitive" was fun.

Low-Skilled Students and Fun: Cooperation. It should be noted here that there were very few low-skilled students who volunteered for this study. Out of 24 students, there were only two low-skilled girls who took part in the study. These two low-skilled students seemed to highlight cooperation when they spoke about fun in physical education.

In one school, there was general excitement regarding an original game a teacher had created. This game was a variation of tag. In an observation of this game, the students played enthusiastically, as they made strategies with each other to earn points for their team. One student was especially excited about this game, and when asked why she liked it, she stated "it is really grown-up, because it's (laughs) like 'yo, it's our country, wanna make alliances, so we can fight together."' During this game, she was actively participating and making strategies with other students.

In another school, a student felt that she enjoyed basketball. She would later add, "in gym I don't think it's like an individual thing; it's kinda a group effort." This student also noted that, although she liked the basketball unit, she did not enjoy track and field. She noted that people did not work together when "playing track and field, uhmmm, it's you, and you don't have anyone to help you or to fall back on for help, I mean, yeah."

The behavior followed these feelings as this student actively participated in an ultimate Frisbee game, but decided not to participate when the class was playing a game of basketball dodgeball, a negative sum game that combined basketball and dodgeball. In an observation of ultimate frisbee game students tried to help each other verbally, creating an atmosphere of cooperation. An atmosphere of cooperation was not created, however, for the observed basketball dodgeball game. In this game students tried to either make a basket for extra points or eliminate another students for points. The basketball dodgeball games were a negative sum activity, and students, rather than working with others, were trying not to get hit by the ball. Students who were not skilled at this game appear to want to avoid participation.

\section{All Students Are Not Developing Skill During Competitive Activities}

The second theme revealed that students overall felt that skill was a necessary part of competition, not everyone, however, was developing skill. Students who had not developed the skill to enter game play, did not have the opportunity to pass to other students and were often seen as standing around. Although students were excited about the many competitive activities offered, they were not given enough time to explore these activities as fully as they would like before starting the next unit. Steve, a moderate-skilled student, raised this concern when discussing the 
units offered during the year. He brought up why he might not be improving in certain units as "we don't have enough time" to improve. In addition, at another school, Dorothy, a moderate-skilled student stated, "we do one thing, and we move on. We do the next part, we don't really get to practice that much, [and] we don't really get better."

Passing, as a Rite of Passage. Students in this study felt that physical education class was an important place to learn new activities. When placed in game-like situations, however, some students had more opportunities than others. Those with skill had many opportunities to apply skills during game play. Conversely, those without skill in certain activities had very few opportunities. This participation gave students a sense of being included, whereas students who were not skilled often were pushed aside. One component of skill in competitive game play is passing. Passing is an important part of competitive sports in physical education. Students without prompting discussed the skill of passing and how it initiates one into game-play. The skill of passing was mentioned in several focus groups as a form of improving in activity. Improving is being able to pass, or receiving a pass.

Malley, a high-skilled girl, when asked how she knew she was improving, stated "they start passing to you more often." Later she would add, "well actually, you sorta feel like your just getting better, uhmmm, like, for basketball, you feel like, oh, you make more shots, you get passed to more." During observations of a game of five-on-five Malley was passed to often.

In another focus group, Jo, a moderate-skilled girl, when asked how she knew she was improving responded,

Like, you feel more, like, comfortable in soccer, if someone passes the ball, you know what to do with it. You just don't stand there and walk along thinking the ball is going to get stolen away from you, but when you know what you're doing you run. . . pass it off to someone, or you try to make the goalie shot.

Students who can pass the ball were considered "good." These "good people" are also seen as students who are skilled at passing. Dorothy, a moderate-skilled girl, who played a lot in that game, has another definition of the "good people." The good people are those who give passes to people who do not get a chance. "Sometimes people pass to people who they think should get a chance, that aren't being passed to that much. Cause, I don't know, those are good people." Dorothy, however, soon changes this statement, agreeing with Ivan, another member of the focus group, that, "the majority of time, the people throw to the better people."

While some schools made an effort to implement a passing rule, other schools did not. Passing was as issue brought up in several focus groups. While students who are skilled receive opportunities to play, students who are not as skilled might not get as many opportunities. Carol, a low-skilled student brought up this concern passing with Malley, a high skilled-girl,

Carol: [your're in a game] right in front of them, and would say 'oh my God, I am here-pass the ball to me,' instead they throw it that way, far down and then we miss. .

Malley: I don't agree with that, because I would get passed to a lot. I know that. 


\section{Carol: You're good}

In observations this was confirmed, as Malley, a high-skilled player was passed to often, and Carol, a low-skilled player, was not passed the ball.

Standing Around. Students who are not given the opportunity to play are seen standing around. Malley stated that, students who are not passed to "don't get to do anything, and they stand around." In another school, a similar concern of students 'staying back,' or in this case 'standing,' also arose. In observations of one class, it seemed that all the students were participating in the game, and as semiactive sideline players. In a focus group of this class, the sidelines were mentioned, as helping a player to score a goal, underscoring the students' teamwork. Oscar, a moderate-skilled boy, however, felt that students on the sidelines sometimes did not participate. He felt that the competitive students "actually pass the ball," whereas "the not so competitive people are against the wall." Mia, a moderate-skilled girl, confirmed his view, as she mentions that, "there are people who stay in the corner."

\section{The Structure of Competitive Activities Affects Student Experience}

The third theme indicates how competitive activities are structured can influence students' experience. Students were asked about their perceptions of competition in physical education class. How activities are structured and the leadership roles that are given can affect a student's experience in competitive activities in physical education class. If students "hog the ball" or if either winning or losing becomes too important, the student's experience in competitive activities in physical education can be adversely affected. Therefore, the way the teacher structures competitive activities is a crucial part of a student's experience in physical education class.

Structuring Teams. Students understood that teams divided evenly were crucial for successful game play. Teachers in all the schools made an effort to create even teams. Although this might be the case, students might perceive that the teams were not even. This was illustrated by one high-skilled girl who felt that the teams were not picked fairly by the teacher. This high-skilled girl felt that she did not like it when the teacher picked the team, because "it was not fair."

In this game, when the teacher was asked if the teams were divided by skill, the teacher responded, "Yes usually, but for this, this was their first time we played the game, but it worked out." This comment suggests that the teacher knew that there might be a disparity in the way the teams had been assigned. Although this might have been the case, however, the teacher suggests that the teams chosen for the game worked well. It is interesting to note, that the high-skilled student's comments did not agree with her teacher's, as she did not think that the team selection "worked out."

Team Leaders. Students felt that classmates who had attained skill would assume leadership roles, such as team leaders. While the majority of teams had been picked before observations of the classes, students agreed that the "good" students or students with skill were chosen for leadership positions, sometimes to the exclusion of lower-skilled students as one low-skill girl stated, "Coach chose me as captain, but that boy took over." 
"Hogging the Ball." Students with skill would also take over game play by "hogging the ball." While some schools implemented a passing rule, others did not. In several observations students were seen displaying this behavior and this was a theme that ran throughout the focus group interviews. Sally, a high-skilled girl, brought up not sharing the ball in an interview, as one thing she disliked about competition, by stating, "if you're on the team not sharing the ball, or,... not giving other people a chance to play, and, and if they win, cheering for themselves." Geoff, a moderate-skilled boy, suggested when discussing strategies, that ball hogs want all the "glory" and will only pass the ball to the good players or the "MVP's."

Students Who Mocked When Winning or became Too Serious When They Lost. Finally, the environment created was an important factor in student enjoyment of competitive activities. This study revealed that students enjoyed working with others in physical education class and being able to learn new activities. Students were concerned, however, about a negative atmosphere that was created when competitive activities were taking place. They revealed that their classmates, sometimes shouted down students who did not have the skill to participate. In other instances winning and losing were taken too far. Supported by observations, students would often gloat or mock when they won, or become too serious when they lost. As one student stated,

Yeah, or I think you can just compete for the fun of competing. People take it so far; these are middle school sports, this isn't the World Series, this isn't the Super Bowl. This is middle school sports, people, people make a big deal out of it. It takes the fun out of it.

\section{Discussion}

This study documented how students feel and what they think when placed into competitive activities in physical education class. In their own words, and supported by observations, students gave an analysis of their experiences in competitive sport in physical education. Their experiences in competitive activities in physical education mirror and have added to many of the topics that have been presented in the literature. While students are enjoying the many competitive activities that are offered, they would like to have more opportunities for success.

Attitude can be affected by the experiences in physical education class participation (Subramaniam \& Silverman, 2002). A prominent theme in this study was that according to skill level, students had different experiences in competitive activities and their perceptions were based on these experiences. Skill level was a determinant of how the students participated in competitive activities in physical education class. Attitude theory suggests that attitudes can be either negative or positive and these attitudes can affect both perceptions and behavior (Zimbardo \& Leippe, 1991).

It appears the participants' attitude might have been affected in a negative manner, if students did not have the skill to participate in game-like situations. In addition the beliefs or perceptions that were held toward the activities that they participated in could have been affected (Pajares, 1992; Zimbardo \& Leippe, 1991). As competitive activities comprise many of the experiences that students are 
offered in physical education class, it is relevant to examine how those activities are structured so students might experience success.

Student perceptions revealed class environment and the way tasks are structured are a crucial part of students' enjoyment. Tasks and the task presentation in competitive activities may or may not allow opportunities for success and are an integral part of the learning process (Rink, 2001; Silverman et al., 1995; Subramaniam \& Silverman, 2007). As the students discussed they are often required to participate in competitive activities for which success is unlikely and if students cannot participate in an activity to the fullest extent their enjoyment likely will be effected.

It should be noted that within this study, only two low-skilled students participated. Perhaps low-skilled students were hesitant to express their views. There is a possibility that this might have influenced the results. Moderate-skilled students, however, brought up many of the issues that were mentioned by the low-skilled students, as they often felt that skill was essential to participation in physical education class. This supports the literature, as skill is an indicator of participation (Carlson, 1995; Portman, 1995; Silverman, 2005; Subramaniam \& Silverman, 2002).

Tasks and the way they are structured might enhance or impede a student's skill acquisition. This study showed that skill was an important part of participation. The literature supports the conclusions that students, who do not have the skill to participate, might not be included in an activity, or they might stop participating all together (Carlson, 1995; Cothran \& Ennis, 1999; Portman, 1995; Roberts, 2001; Subramaniam \& Silverman, 2000). The theory of reasoned action (Ajzen, 2005) suggests that students' knowledge may affect how students participate in an activity (Ajzen, 2005). The findings showed, the lack of skill hindered students' participation and ultimately student learning in an activity, and might have affected the students' experience.

Lack of time to practice appropriately was an element shown for not attaining skill. Time and appropriate practice is crucial for student success (Buck, Harrison, \& Bryce, 1991; Meltzer, 1989; Silverman, 1985, 1990, 1993, 2005; Silverman, Subramaniam, \& Woods, 1998; Simons-Morton, Taylor, Snider, \& Huang, 1993). Students, who did not attain skill, often could not participate when placed in game-like situations. Thus, while "fun" was the focus in many of these competitive classes, not all students might be having the same fun experience. Students, who do not have the skill to participate, might not be included in an activity, or they might stop participating all together (Carlson, 1995; Cothran \& Ennis, 1999; Portman, 1995; Roberts, 2001; Subramaniam \& Silverman, 2000). If the goal is to have students participate in competitive activities and experience success, appropriate practice is a necessary focus. Without skill, it is unlikely students can participate in game-like situations. It is interesting that middle school students understood this, but their teachers often structured class in ways that did not promote opportunities for skill development.

Students perceived that their enjoyment is augmented when activities are presented in a positive environment. In addition, students perceived a positive environment can be fostered in a caring environment (Cothran et al., 2003; Noddings, 2003; Ravizza \& Stratton, 2007). If students are not presented with a positive environment their attitudes can be negatively affected (Subramaniam \& Silverman, 2002, 2007). A prominent theme was the environment that is created as students enter game play is important to consider when structuring activities. A focus on task 
rather than outcome (Ames, 1986; Dweck, 1986; Garn \& Cothran, 2006; Solmon \& Lee, 1996; Tabernero \& Wood, 1999) might be more successful in creating a positive environment. The environment created should stress learning, rather than certain outcomes that might ensue.

Students shared their experiences in competitive activities, and supported by observations, they gave an analysis of their experience in competitive sport in physical education class. Their experiences reflect many of the topics that have been presented in the literature, (Meltzer, 1989; Rink, 1994; Silverman, 1985, 1990; Silverman et al., 1988; Silverman et al., 1995), skill progression, and how tasks are presented especially skill development, appropriate time and practice, and task presentation. This suggests that research on students' perception reinforces other types of physical education research and provides insight into how teachers and class structure impact student skill development and attitude. Future research focusing on both students' and teachers' perceptions and attitudes toward structuring competitive activities would be beneficial in examining how these activities are implemented in physical education class.

It appears essential for educators to create more productive learning opportunities and enjoyable programs for their students in terms of competitive activities and structuring game-play in physical education class. As a negative attitude may affect participation and ultimately how a student learns authentic skills (Ajzen, 2005; Carlson, 1995; Pajares, 1992; Silverman \& Subramaniam, 1999), it might be beneficial for teachers to examine the way competition is structured in physical education class and if it is appropriate before all students obtaining skill. If students are to benefit from physical education and adopt a physically active lifestyle, skill development and enjoyment are critical. The information offered by the students who participated in this study provides a basis for rethinking entrenched strategies to help reexamine the way competitive activities are presented in physical education class and ultimately, the way students' value physical activity.

\section{References}

Ajzen, I. (2005). Attitudes, personality, and behavior (2nd ed.). Berkshire England: Open Press.

Ames, C. (1986). Conceptions of motivation within competitive and noncompetitive goal structures. In R. Schwarzer (Ed.), Self-related cognitions in anxiety and motivation. Hillside, NJ: Erlbaum.

Bogdan, R., \& Biklen, S. (2006). Qualitative research in education: An introduction to theory and practice (5th ed.). Boston, MA: Allyn and Bacon.

Brown, L., \& Grineski, S. (1992). An educational contradiction? Journal of Physical Education, Recreation \& Dance, 63(1), 17.

Buck, M., Harrison, J.M., \& Bryce, G.R. (1991). An analysis of learning trials and their relationship to achievement in volleyball. Journal of Teaching in Physical Education, 10, 134-152.

Carlson, T.B. (1995). We hate gym: Student alienation from physical education. Journal of. Teaching in Physical Education, 14, 467- 477.

Center for Disease Control and Prevention. (2006). Overweight and obesity. Retrieved October15th, 2005 from http://www.cdc.gov/nccdphp/dnpa/obesity.

Cothran, D., \& Ennis, C. (1999). Alone in a crowd: Meeting students' needs for relevance and connection in urban high school physical education. Journal of Teaching in Physical Education, 18, 234-247. 
Cothran, D., Kulinna, P., \& Garrahy, D. (2003). 'This is kind of giving a secret away...": students' perspectives on effective class management. Teaching and Teacher Education, 19, 435-444.

Drewe, S.B. (1998). Competing conceptions of competition: Implication for physical education. European Physical Education Review, 4, 5-20.

Dweck, C.S. (1986). Motivational process affecting learning. The American Psychologist, 41, 1040-1048.

Dyson, B.P. (1995). Students' voices in two alternative elementary physical education programs. Journal of Teaching in Physical Education, 14, 394-407.

Ennis, C. (1996). Students' experiences in sport based physical education: [More than] apologies are necessary. Quest, 48, 453-456.

Ennis, C. (2003). Using Curriculum to Enhance Student Learning. In S.J. Silverman \& C.D. Ennis (Eds.), Student learning in physical education: Applying research to enhance instruction ( $2^{\text {nd }}$ ed., pp. 109-127). Champaign, IL: Human Kinetics.

Garn, A., \& Cothran, D.J. (2006). The fun factor in physical education. Journal of Teaching in Physical Education, 25, 281-298.

Glaser, B.G., \& Strauss, A.L. (1967). Discovery of grounded theory. Mill Valley, CA: Sociology Press.

Goldstein, J., \& Iso-Ahola, S.E. (2006). Promoting sportsmanship in youth sports: Perspectives from sport psychology. Journal of Physical Education, Recreation \& Dance, 77(7), 18-25.

Graham, G. (1995). Physical education through students' eyes and in students' voice implications for teachers and researchers. Journal of Teaching in Physical Education, 14, 478-482.

Hager, P.F. (1995). Redefining success in competitive activities. Journal of Physical Education, Recreation \& Dance, 66(5), 26-31.

Hopple, C., \& Graham, G. (1995). What children think, feel, and know about physical fitness testing. Journal of Teaching in Physical Education, 14, 408-417.

Kohn, A. (1999). Punished by rewards: The trouble with gold stars, incentive plans, A's, praise and other bribes ( $2^{\text {nd }}$ ed). New York, NY: Mariner Books.

Manson, M. (2003). Middle school students' perceptions of skill level and their effects on participation in physical education. Ed.D. dissertation, Columbia University Teachers College, United States-New York. Retrieved August 26, 2008, from Dissertations \& Theses: Full Text database. (Publication No. AAT 3080064).

Meltzer, M. (1989). A review of research on time in sport pedagogy. Journal of Teaching in Physical Education, 8, 87-103.

Morgan, D.L. (1997). Focus groups as qualitative research (2nd ed.). Thousand Oaks, CA: Sage.

National Association for Sport and Physical Education. (2009). Appropriate instructional practice guidelines, K-12: A side by side comparison. Retrieved March $6^{\text {th }}, 2010$ from http://www.aahperd.org/naspe/standards/nationalGuidelines/Apppracticedoc.cfm.

Noddings, N. (2003). Caring: A feminine approach to education. Berkeley University of California Press.

Ntoumanis N. (2001). A self-determination approach to the understanding of motivation in physical education. The British Journal of Educational Psychology, 71, 225-242.

Pajares, F.M. (1992). Teachers' beliefs and educational research: Cleaning up a messy construct. Review of Educational Research, 42, 307-332.

Patton, M.Q. (2002). Qualitative research \& evaluation methods ( $3^{\text {rd }}$ ed.). Beverly Hills, CA: Sage.

Portman, P.A. (1995). Who is having fun in physical education classes? Experiences of six grade students in elementary and middle schools. Journal of Teaching in Physical Education, 14, 445-453. 
Ravizza, D.M., \& Stratton, R.K. (2007). Students' perceptions of physical education teachers' caring. Research Quarterly for Exercise and Sport, 78, 70-72.

Rickard, G.L. (1992). The relationship of teachers' task refinement and feedback to students' practice success. Journal of Teaching in Physical Education, 11, 349-357.

Rink, J. (1994). Task presentation in pedagogy. Quest, 46, 270-280.

Rink, J. (2001). Investigating the assumptions of pedagogy. Journal of Teaching in Physical Education, 20, 112-128.

Roberts, G.C. (2001). Advances in motivation in sport and exercise. Champaign, IL: Human Kinetics.

Sallis, J.F., Prochaska, J.J., \& Taylor, W.C. (2000). A review of correlates of physical activity of children and adolescents. Medicine and Science in Sports and Exercise, 32, 963-975.

Schensul, J.J. (1999). Focus group interviews. In J. Schensul, M. LeCompte, B. Natasai, \& S. Borgatti (Eds.), Enhanced ethnographic methods (pp. 51-114). New York, NY: Rowman \& Littlefield Pub, Inc.

Seidman, I. (2006). Interviewing as qualitative research ( $3^{\text {rd }}$ ed.). New York: Teachers College Press.

Silverman, S. (1985). Relationship of engagement and practice trials to student achievement. Journal of Teaching in Physical Education, 5, 13-21.

Silverman, S. (1990). Linear and curvilinear relationships between student practice and achievement in physical education. Teaching and Teacher Education, 6, 305-314.

Silverman, S. (1993). Student characteristics practice and achievement in physical education. Journal of Educational Research, 87, 54-61.

Silverman, S. (1996). A pedagogical model of human performance determinants in sports. Proceedings of the pre-congress symposium of the 1996 Seoul International Sport Science Congress (vol. I, pp.476-488). Seoul, Korea: Korean Alliance for Health, Physical Education, Recreation and Dance.

Silverman, S. (2005). Low-skilled children in physical education: A model of factors that that impact their experiences and learning. In F. Carrerio da Costa, M. Cloes, \& M. Gonález (Eds.), The art and science of teaching in physical education and sport. Leige, Belguim: University of Leige Press.

Silverman, S., Kulinna, P., \& Crull, G. (1995). Skill-related task structures, explicitness, and accountability: Relationships with achievement. Research Quarterly for Exercise. and Sport, 66, 32-40.

Silverman, S., Tyson, L., \& Morford, L.M. (1988). Relationships of organization, time, and student achievement in physical education. Teaching and Teacher Education, 4, 247.

Silverman, S., \& Subramaniam, P.R. (1999). Student attitude toward physical education and physical activity: A review of measurement issues and outcomes. Journal of Teaching in Physical Education, 19, 97-125.

Silverman, S., Subramaniam, P.R., \& Woods, A.M. (1998). Task structures, student practice, and student skill level in physical education. The Journal of Educational Research, 91, 298-306.

Simons-Morton, B G, Taylor, W C, Snider, S A, \& Huang, I. W. (1993). The physical activity of fifth-grade students during physical education classes. American Journal of Public Health, 83, 262-264.

Solmon, M. (1996). Educational impact of motivational climate on students' behaviors and perceptions in a physical education setting. Journal of Educational Psychology, 88, 731-738.

Solmon, M. \& Lee, A. (1996). Entry characteristics, Practice variables, and cognition: Student mediation of instruction. Journal of Teaching in Physical Education, 15, 136-151.

Strauss, A.L. (1987). Qualitative analysis for social scientists. Cambridge, UK: Cambridge University Press. 
Subramaniam, P.R., \& Silverman, S. (2000). Validation of scores from an instrument assessing student attitude toward physical education. Measurement in Physical Education and Exercise Science, 4, 29-43.

Subramaniam, P.R., \& Silverman, S. (2002). Using complimentary data: An investigation of student attitude in physical education. Journal of Sport Pedagogy, 8(1), 74-79.

Subramaniam, P.R., \& Silverman, S. (2007). Middle school students' attitude toward physical education. Teaching and Teacher Education, 23, 602-611.

Tabernero, C., \& Wood, R.E. (1999). Implicit theories versus the social construal of ability in self-regulation and performance on a complex task. Organizational Behavior and Human Decision Processes, 78,104-127.

Tjeerdsma, B.L., Rink, J.E., \& Graham, K.C. (1996). Student perceptions, values, and beliefs prior to, during, and after badminton instruction. Journal of Teaching in Physical Education, 18, 216-233.

Zimbardo, P.G., \& Leippe, M.R. (1991). The psychology of attitude change and social influence. Philadelphia, PA: Temple University Press. 